\title{
Top-down interactions and temperature control of snow crab abundance in the northwest Atlantic Ocean
}

\author{
Stephanie A. Boudreau*, Sean C. Anderson, Boris Worm \\ Biology Department, Dalhousie University, 1355 Oxford Street, Halifax, Nova Scotia B3H 4J1, Canada
}

\begin{abstract}
In much of the northwest Atlantic Ocean, commercially important snow crab Chionoecetes opilio stocks have increased in abundance since the decline and collapse of major groundfish stocks such as Atlantic cod Gadus morhua. We examined 3 hypotheses to explain variation in the abundance of snow crabs across 10 regions: (1) climate control of both species, (2) top-down control of snow crab by cod and (3) bottom-up control of cod by snow crab. We tested these hypotheses by analyzing time series data of cod and crab abundance indices and temperature via meta-analysis of full and partial correlation coefficients. We found that temperature had an opposing effect on the 2 species: snow crab abundance was negatively correlated with temperature at 7 to $10 \mathrm{yr}$ lags, whereas cod and temperature were positively related at 1 to $7 \mathrm{yr}$ lags. Controlling for the effect of temperature, our meta-analysis revealed significant negative correlations of snow crab and cod abundance, with cod leading snow crab by up to a 5 yr lag. This suggests a top-down effect on older juvenile and subadult snow crab. We found no evidence of a bottom-up effect of snow crab on cod. Negative correlations between cod and crab abundance were observed both at the warmer and colder portions of their ranges. These results suggest that snow crab abundance is largely influenced by temperature during the early postsettlement years and becomes increasingly regulated by top-down mechanisms during the years approaching fishery recruitment. The method presented in this paper is generally useful to test ecological hypotheses from time series data, particularly where multiple causal mechanisms are suspected.
\end{abstract}

KEY WORDS: Predation - Species interactions - Climate - Snow crab - Chionoecetes opilio . Atlantic cod · Gadus morhua $\cdot$ Meta-analysis

\section{INTRODUCTION}

The decline and collapse of Atlantic cod Gadus morhua stocks in the NW Atlantic Ocean over the last 2 to 3 decades, and coinciding increases in various crustacean species since, have resulted in a changed ecosystem and a sharp transition in fishing effort from large groundfish species to invertebrates (Worm \& Myers 2003, Frank et al. 2005, Anderson et al. 2008). Fisheries for American lobster Homarus americanus, snow crab Chionoecetes opilio and northern shrimp Pandalus borealis are currently the most valuable fisheries in Atlantic Canada (DFO 2009a). Snow crab populations experienced large interannual variation with sustained increases over much of the 1990s (e.g. Conan et al. 1996, Sainte-Marie et al. 1996, Tremblay 1997, Caddy et al. 2005; Fig. 1). It is unclear which ecological factors influenced this variation and whether they relate to population dynamics. Such factors could include density dependence and cannibalism (e.g. Sainte-Marie et al. 1996, Lovrich \& Sainte-Marie 1997, Sainte-Marie \& Lafrance 2002), species interactions (e.g. predation; Bailey 1982, Tremblay 1997, Chabot et al. 2008), environmental forcing (e.g. temperature fluctuations; Taylor et al. 1993, Conan et al. 1996, Tremblay 1997) or a combination of these.

The relative importance of these factors in the NW Atlantic Ocean cannot be resolved from an analysis of single time series owing to their limited length (20 to $31 \mathrm{yr}$ ) and confounding factors (e.g. sample size, vari- 

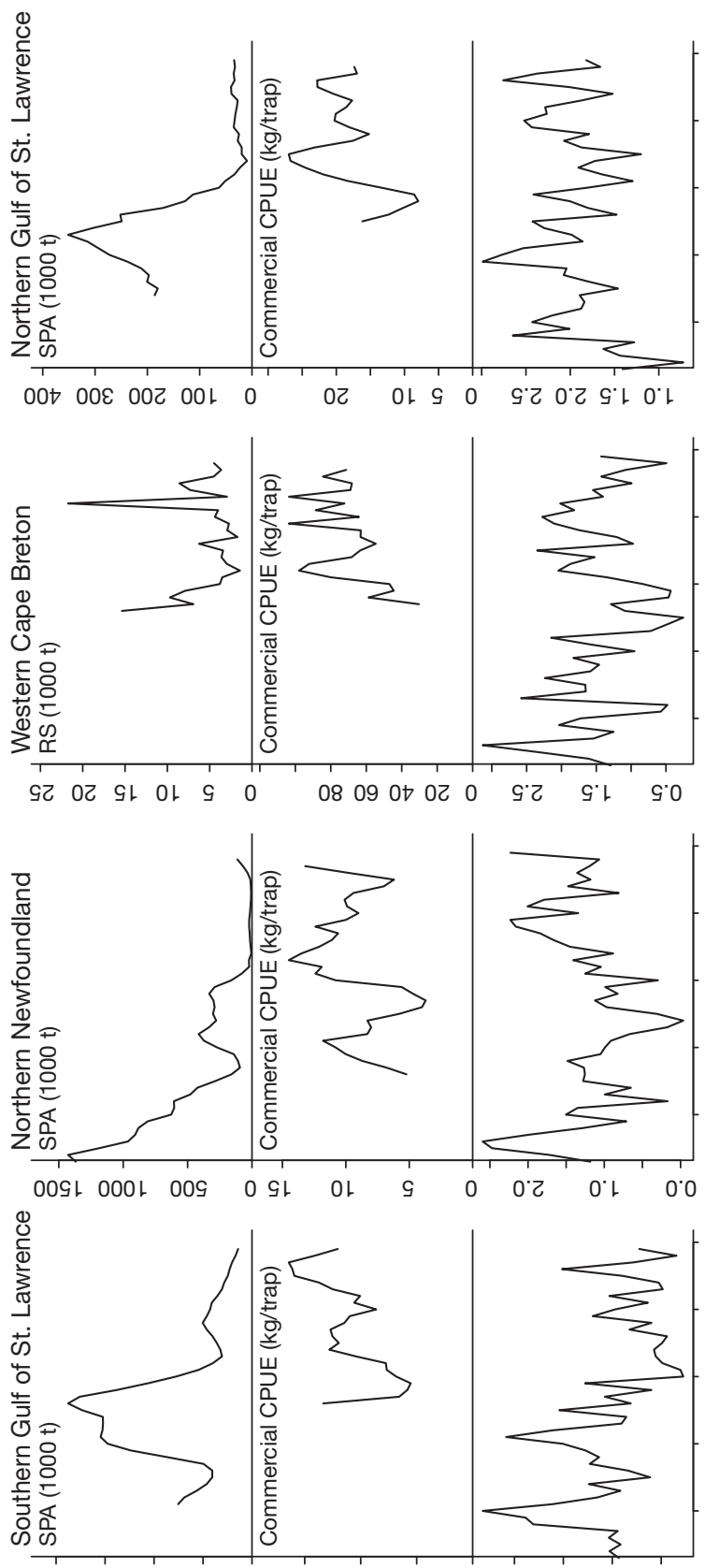

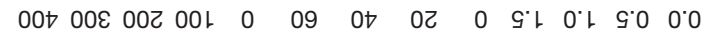

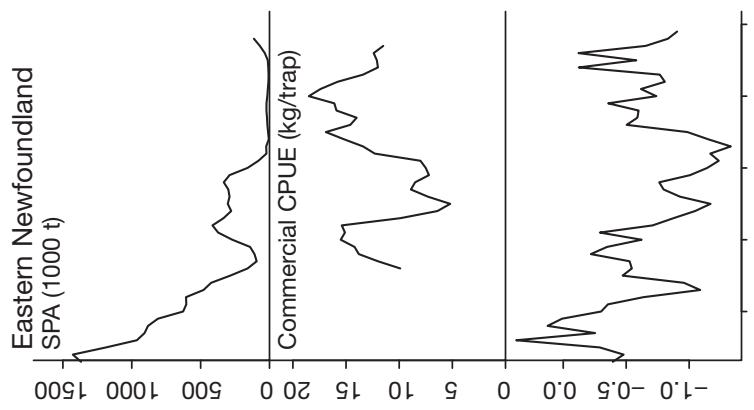

poo

qexo

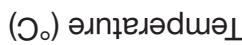

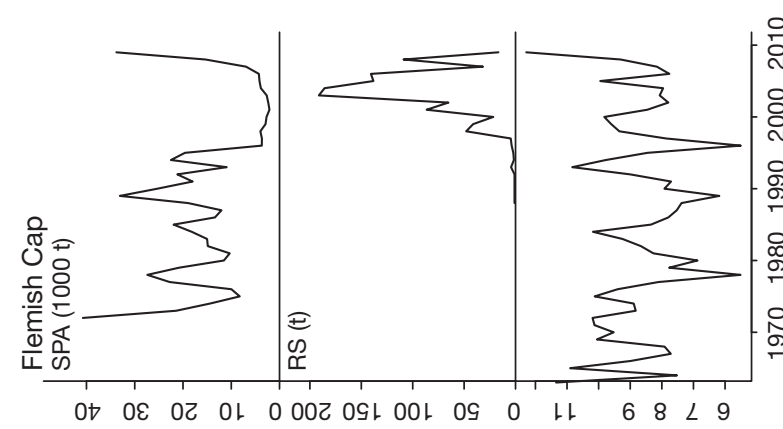

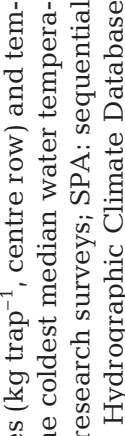

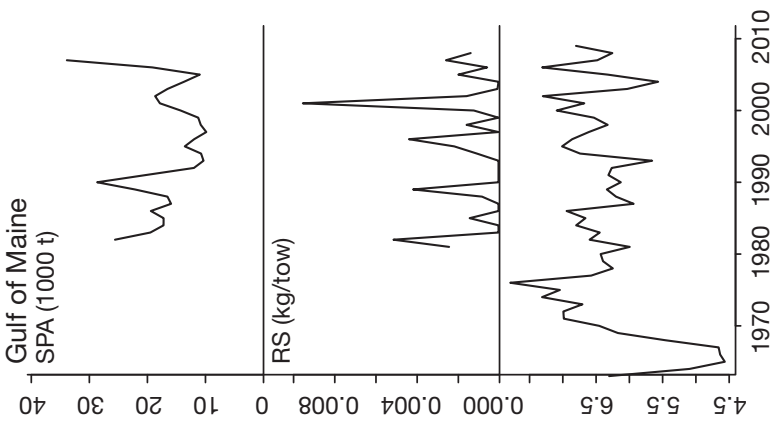

Ð

节 वै

엉

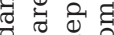

콣

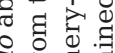

원워

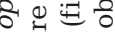

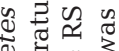

¿

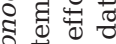

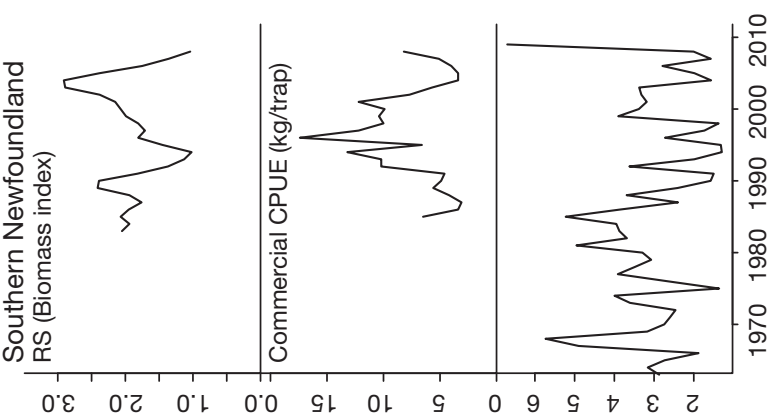

记完范

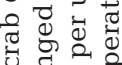

उ 듐 명

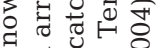

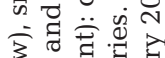

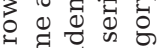

유메 Ð

후워

广。

응 정 중

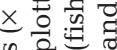

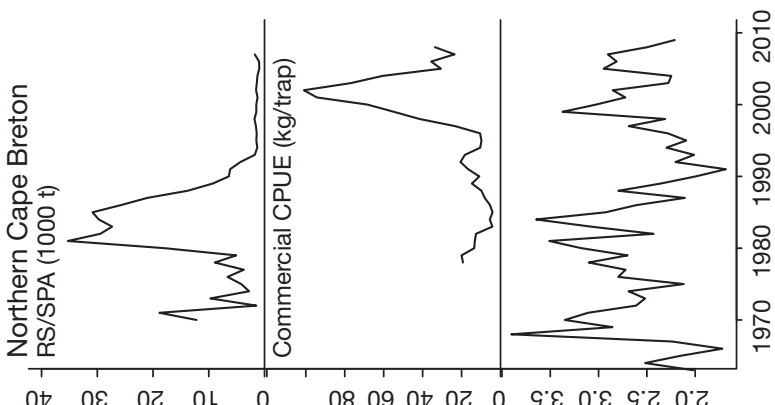

떵용

घ3记

ขิ $ণ$

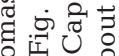

의

욜

客 월 至

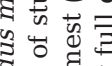

ช च छ

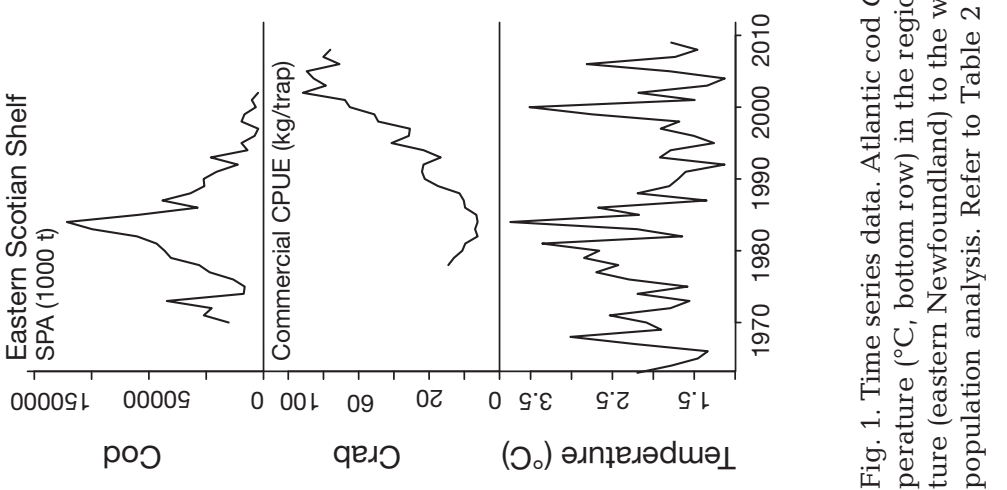


ability), both of which limit statistical inference. When analyzed together, replicated time series in multiple regions can provide insight into food-web interactions (e.g. Worm \& Myers 2003). Here we introduce an extended meta-analytic approach to explore the causes of variation in snow crab abundance and to test multiple ecological hypotheses about the structuring factors of marine ecosystems.

In this context, the overfishing and collapse of NW Atlantic cod stocks (Myers et al. 1996, 1997a) may be viewed as the replicated realization of a large-scale predator removal experiment. Analyses of stomach contents demonstrate that various crabs, including snow crab, are important prey of cod in the Atlantic Ocean (see Table 1). However, previous analyses have yielded conflicting conclusions about the role Atlantic cod plays in regulating snow crab abundance. Bailey (1982) found strong evidence of a predator-prey relationship whereas Waiwood \& Elner (1982) did not. Chabot et al. (2008) found that snow crab comprised less than $10 \%$ of stomach content mass in Atlantic cod from the Gulf of St. Lawrence (GSL). By comparison, northern shrimp comprises from 5.0 to $9.3 \%$ of cod stomach contents (averaged across studies), and cod appears to exert strong top-down control of shrimp stocks (Worm \& Myers 2003 and references therein). Further, this interaction was found to be temperature dependent, with stronger evidence of top-down control in colder temperatures (Worm \& Myers 2003, Frank et al. 2007).

Snow crabs in Atlantic Canada are generally found at temperatures between -0.5 and $5^{\circ} \mathrm{C}$ (Elner 1982, Tremblay 1997), and bottom temperature is thought to be an important determinant of snow crab distribution. Along the Scotian Shelf, snow crabs are predominantly found in areas where the bottom temperature does not exceed $7^{\circ} \mathrm{C}$ (Tremblay 1997). At $7^{\circ} \mathrm{C}$ energetic restrictions come into play for mature males as metabolic costs begin to rise faster than energy inputs (Foyle et al. 1989). A decline in mean bottom temperature from -0.6 to $-1.4^{\circ} \mathrm{C}$ in the 1980 s off southeastern Newfoundland is thought to have interrupted the moult cycle of the snow crab, and the absence of newly moulted recruits contributed to a collapse of the crab fishery (Taylor et al. 1993). Though environmental conditions may not fully explain the cyclical nature of snow crab populations (Conan et al. 1996, Sainte-Marie et al. 1996), it is possible that lower temperatures after 1984 may have contributed to an expansion in habitat (e.g. Tremblay 1997) (Fig. 1). Water temperature and substrate are also thought to be important for the survival of early life stages of snow crab (e.g. Lovrich et al. 1995, Dionne et al. 2003).

By expanding on the meta-analytic methods established by Worm \& Myers (2003), we attempted to test both predation and climate hypotheses by correlating snow crab abundance, Atlantic cod biomass, and ocean temperature. Specifically, our goal was to examine 3 competing hypotheses to explain variation in snow crab abundance: (1) climate control, which should result in correlations with environmental variables such as ocean temperature; (2) top-down control, which should result in negative correlations between cod (predator) and crab (prey); and (3) bottom-up control, which should result in positive correlations between cod and crab abundance if both populations are driven by factors regulating productivity. We examine these hypotheses simultaneously, accounting for possible time lags, for 10 regions ranging from the northern to the southern limits of snow crab populations on the NW Atlantic continental shelf.

\section{METHODS}

Species. In the NW Atlantic Ocean, male and female snow crabs can reach a maximum carapace width (CW) of 150 and $80 \mathrm{~mm}$, respectively, after their terminal moult (Chabot et al. 2008) to maturity (Conan \& Comeau 1986). Only males with a CW greater than $95 \mathrm{~mm}$ are harvested commercially (Sainte-Marie et al. 1996, Choi \& Zisserson 2008) and females are not retained (Miller 1976). On the Scotian Shelf, snow crabs are usually most abundant between 100 and $250 \mathrm{~m}$ depth and are found at cold temperatures between $<1$ and $3^{\circ} \mathrm{C}$ (Tremblay 1997). It takes approximately 9 (postsettlement) to 11 (postegg extrusion) yr for male snow crab to reach the minimum $\mathrm{CW}$, and after the terminal moult, their life expectancy is approximately 5 to 8 yr (Sainte-Marie et al. 1995, Choi \& Zisserson 2008, Fonseca et al. 2008). In the GSL, snow crabs migrate to shallow $(<35 \mathrm{~m})$ waters to moult in the early spring (Sainte-Marie \& Hazel 1992, Lovrich et al. 1995). Both sexes separate by depth and aggregate according to maturity, shell condition and size. Primiparous females and small adult males are generally found in shallower water whereas multiparous females and large adult males are found in deeper water (Sainte-Marie \& Hazel 1992).

Atlantic cod are highly migratory (ICES 2005) and feed opportunistically on benthic crustaceans and other invertebrates before becoming increasingly piscivorous with size (Hanson \& Chouinard 2002, Link \& Garrison 2002). Atlantic cod can be as large as $150 \mathrm{~cm}$, live 20+ yr and occupy depths from 1 to $600 \mathrm{~m}$ (Pálsson 1994). Atlantic cod in the NW Atlantic Ocean are found at a range of depths and temperatures. For example, on the Flemish Cap (FC) they can be found from 150 to $500+\mathrm{m}$ at temperatures ranging between 3.5 and $4.5^{\circ} \mathrm{C}$ (ICES 2005). On Georges Bank (in the Gulf of 
Maine [GOM]) they are found at their upper range of temperatures from 10 to $14^{\circ} \mathrm{C}$ (annual mean at $100 \mathrm{~m}$ ) (ICES 2005). In eastern Newfoundland (ENL) they are found at their lower range of temperatures from $<0$ to $6^{\circ} \mathrm{C}$ (ICES 2005). Stomach sampling confirms that Atlantic cod prey on snow crab and that their ranges overlap (Table 1).

Data. We compiled all available time series of Atlantic cod and snow crab abundances in the NW Atlantic Ocean (Table 2, Fig. 2 for study regions). For cod populations, we used biomass estimates derived from random stratified research surveys (RS) and from sequential population analyses (SPA) as presented in the official Canadian Department of Fisheries and Oceans (DFO) stock assessments (Table 2). In Canada, snow crabs were not recorded consistently in the standard trawl surveys in most of the east coast regions until the mid-1990s (Table 2). Therefore, in our analyses, we used fishery catch per unit effort (CPUE) data (catch per trap haul) for those regions. For snow crabs in the $\mathrm{FC}$ and GOM we used data from otter trawl surveys in which all sizes of crab encountered were recorded and included in the present data set and analysis (i.e. not only legal-sized males). These surveys are variable owing to the low densities of snow crab but can still be used to examine long-term population trends.

In Canada, localized exploitation of snow crab began in the 1960s through incidental catch by groundfish fleets (Bailey \& Elner 1989, DFO 2009b,c). Directed fishing with baited traps was introduced in the late 1960s (Bailey \& Elner 1989, DFO 2009c) and fishing pressure intensified and expanded from the mid-1970s (Bailey \& Elner 1989) through the mid-1990s, with a decline in catches through the 1980s (Tremblay 1997, DFO 2009b,c,d). By the early 1990s, fishers were exploiting most of the snow crab's distribution along the Scotian Shelf (Tremblay 1997, DFO 2009b) and expanding to offshore regions in Newfoundland (DFO 2009c).

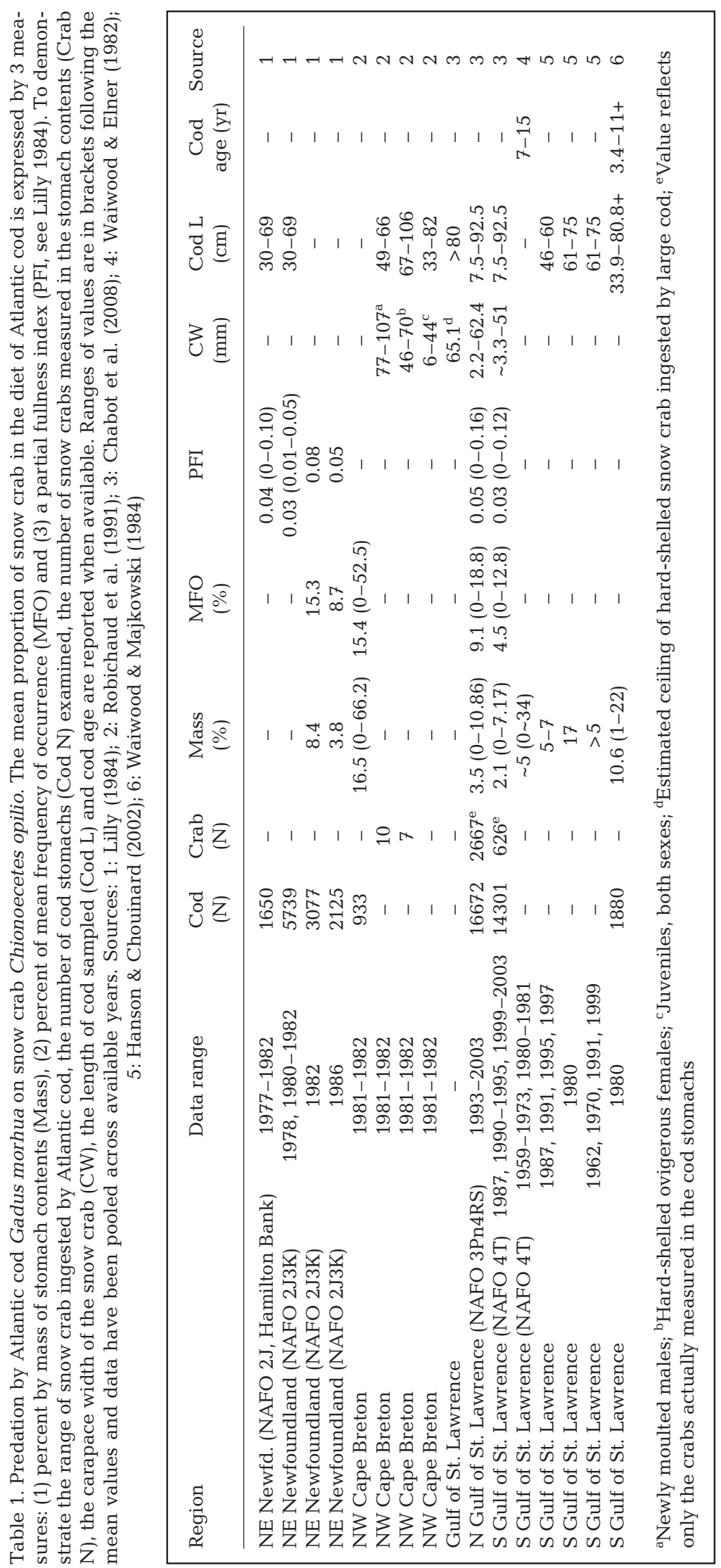




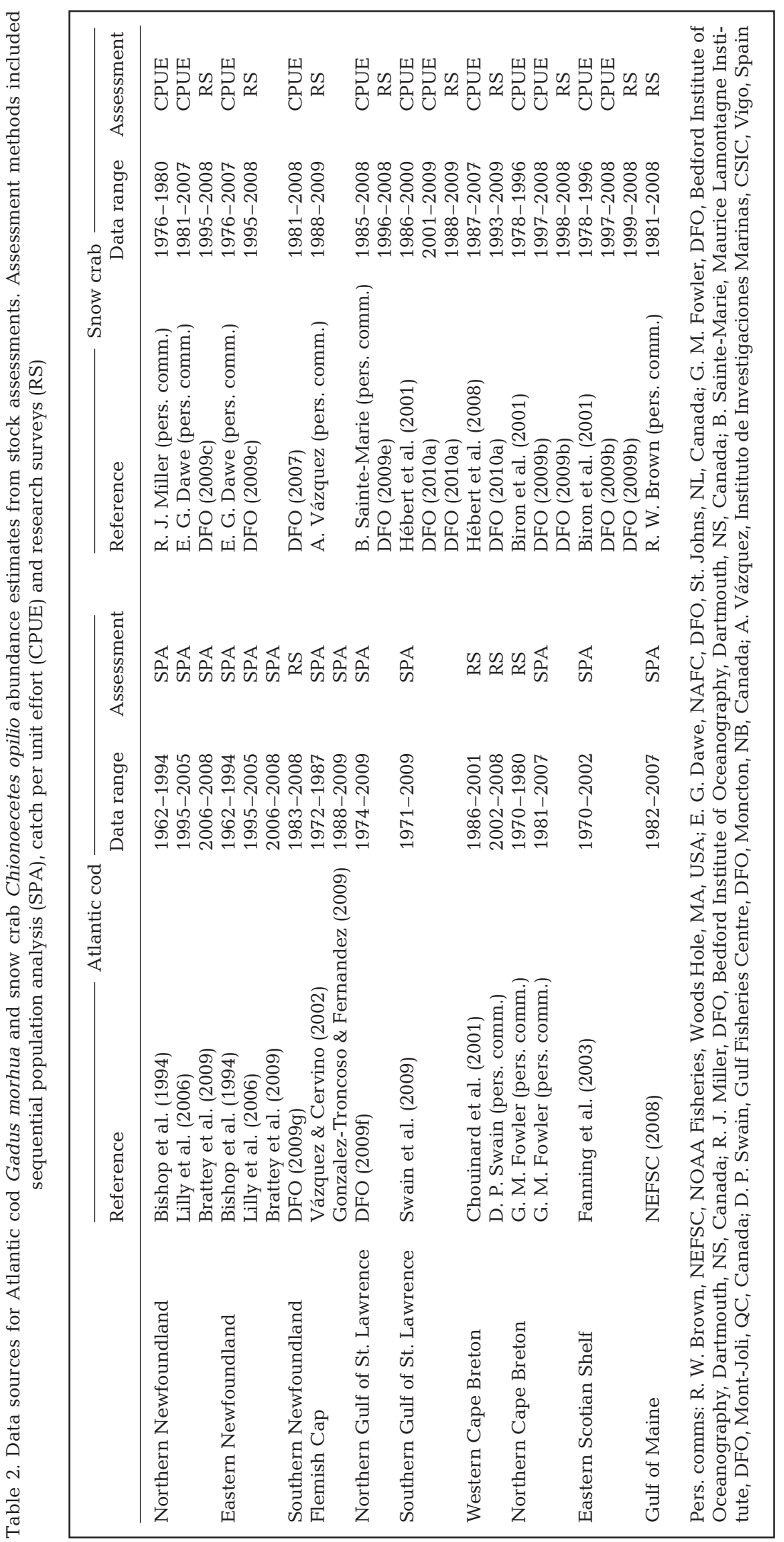

CPUE may not always reflect changes in species abundance (e.g. Harley et al. 2001) and could be sensitive to changes in fishing efficiency (e.g. Myers \& Cadigan 1995, Hutchings 1996, Swain \& Wade 2003) and target species catchability (e.g. Murray \& Seed 2010). Still, CPUE is commonly used as an index of abundance when fisheries-independent data are unavailable. CPUE in the northern Gulf of St. Lawrence (NGSL) is the only time series that has been standardized by the DFO to account for season, gear type and soak time (DFO 2009e). Where possible, we examined how well fishery CPUE tracked biomass estimates from research surveys using linear regression.

To consider the effect of temperature on both cod and crab populations we assembled temperature time series at depths where cod and crab distributions overlap (150 $\pm 75 \mathrm{~m}$ depth; $350 \pm$ $100 \mathrm{~m}$ depth for the FC). We obtained temperature data from the DFO Hydrographic Climate Database (Gregory 2004) and used generalized linear models with year and month as independent variables to derive adjusted mean annual temperature trends.

Analysis. To stabilize variances we log-transformed all cod and crab time series. We corrected for autocorrelation by adjusting the effective degrees of freedom of the correlation coefficients using the modified Chelton method (Pyper \& Peterman 1998). We applied a Fisher's $z$ transformation to the correlation coefficients before combining them to normalize their distribution and stabilize their variance (Stuart \& Ord 1987, Worm \& Myers 2003). Corrected correlation coefficients were combined by means of random-effects inverse-varianceweighted meta-analysis (Hedges 1994, Worm \& Myers 2003). When the assumption of homogeneous effect sizes is violated, e.g. when comparing populations from substantially different habitats, the random-effects approach is more realistic than the fixed-effects approach (Hedges 1994). 


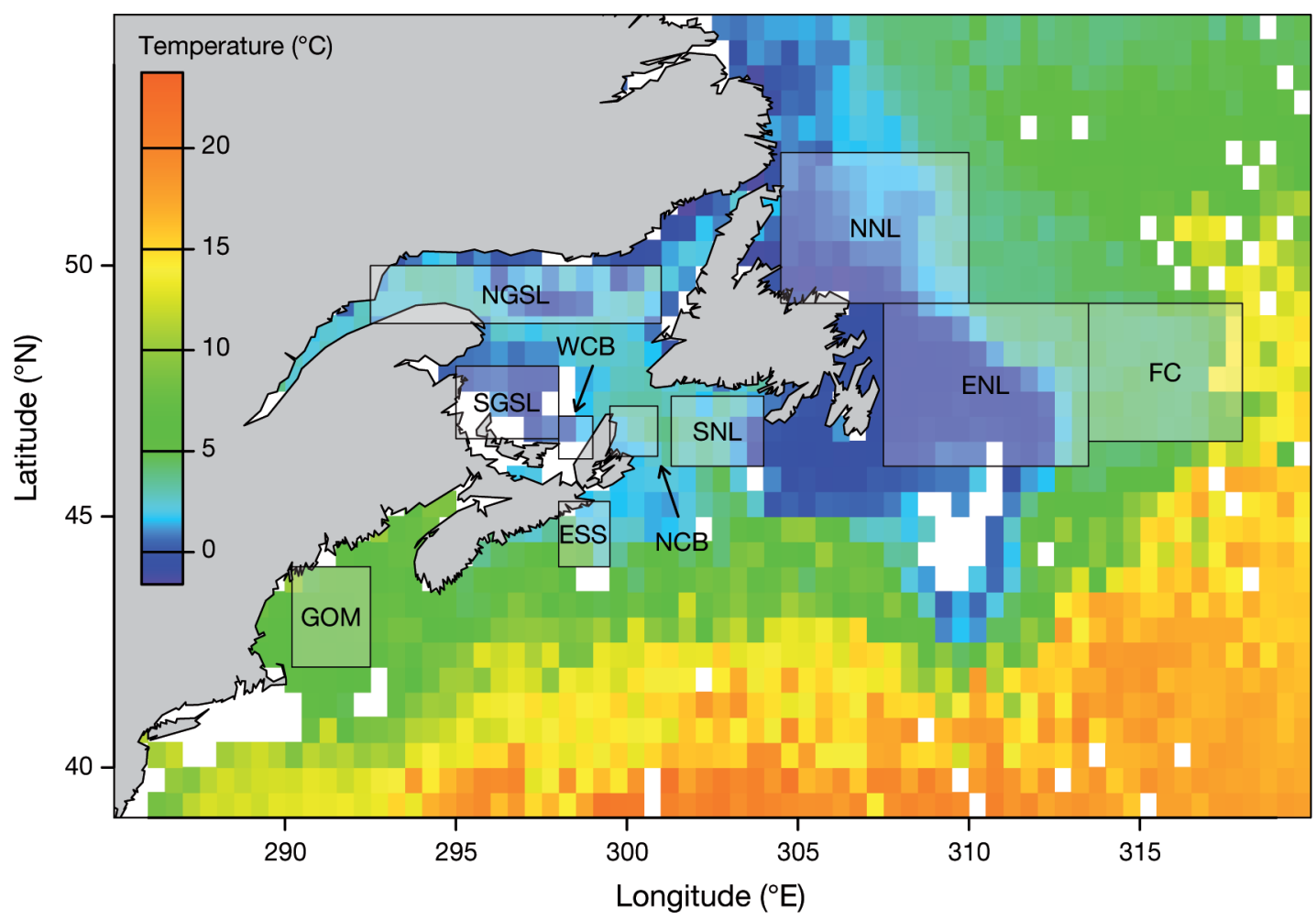

Fig. 2. Study regions. To illustrate temperatures regimes we underlayed the median temperature across all available samples from 1 January 2005 to 1 January 2010 at $150 \pm 75 \mathrm{~m}$ depth at $0.5^{\circ} \times 0.5^{\circ}$ resolution. NNL: northern Newfoundland; ENL: eastern Newfoundland; SNL: southern Newfoundland; FC: Flemish Cap; NSGL: northern Gulf of St. Lawrence; SGSL: southern Gulf of St. Lawrence; WCB: western Cape Breton; NCB: northern Cape Breton; ESS: eastern Scotian Shelf; GOM: Gulf of Maine

We extended the meta-analytic approach of Worm \& Myers (2003) to include testing for the effect of cod biomass on crab abundance after accounting for the effect of water temperature. We therefore conducted 4 separate meta-analyses. To test the hypothesis that changes in population abundance were related to climate, we separately analyzed correlations between (1) cod biomass and (2) crab abundance with temperature. To test the top-down and bottom-up species interaction hypotheses, we analyzed correlations between cod biomass and crab abundance. We show meta-analyses of both the (3) full correlations (without taking into account the effect of temperature) and (4) partial correlations (taking into account the effect of temperature). Therefore, for the partial correlations, we first regressed cod and crab series with temperature separately and then regressed the residuals from those models against each other.

We conducted meta-analyses at a variety of time lags to test a suite of hypotheses. It takes snow crab approximately 9 yr postsettlement to moult to legal size and they recruit $1 \mathrm{yr}$ after their terminal moult (SainteMarie et al. 1995). The larval and embryonic life stages span 12 yr (Sainte-Marie 1993, Comeau et al. 1999). We therefore examined lags of 0 to $12 \mathrm{yr}$ for each spe- cies with temperature and both positive and negative lags up to 12 yr for species interactions. We explored the partial correlations by controlling for the effect of temperature at several lags (5 to $9 \mathrm{yr}$ ) approximating the year of fishery recruitment. In the final analysis, we controlled for the effect of temperature at a $7 \mathrm{yr}$ lag, as suggested by the maximum correlation in our metaanalysis of temperature with cod and crab abundance (see 'Results'). At positive lags (cod leading snow crab) negative correlations would suggest top-down control of cod on crab. Positive correlations (at negative or positive lags) would suggest bottom-up control by factors affecting the productivity of both species. At negative lags (snow crab leading cod) positive correlations would suggest bottom-up control, potentially by crab as prey for cod.

Recruitment among fish populations within $500 \mathrm{~km}$ is frequently correlated (Myers et al. 1997b). Therefore, we tested the sensitivity of our conclusions to potential spatial correlation by repeating our analysis after removing the data from the southern Gulf of St. Lawrence (SGSL), western Cape Breton (WCB), northern Cape Breton (NCB) and ENL, such that all remaining regions were $>500 \mathrm{~km}$ apart. We further tested for robustness by grouping some of the regions 
that demonstrated similar trends and repeating the analyses. The regional groupings tested were: (a) SGSL and NGSL, (b) Northern Newfoundland (NNL) and ENL, (c) ENL, SGSL and NNL, (d) NCB and Southern Newfoundland (SNL), (e) NCB, SNL and FC and (f) all regions excluding the GOM and FC (i.e. using only fishery-dependent CPUE).

\section{RESULTS}

\section{Diet studies}

A literature survey confirmed that snow crabs are an important component of Atlantic cod diet (Table 1). A wide range of carapace sizes (2.2 to $107 \mathrm{~mm} \mathrm{CW})$ were found in Atlantic cod of 18 to $106 \mathrm{~cm}$ length. Snow crabs were found in 4.5 to $15.4 \%$ of cod stomachs and contributed 2.1 to $16.5 \%$ of cod stomach content by weight (Table 1 and references therein). In cases where the ingested snow crabs were measured, most were juveniles, and a larger range of snow crab sizes were recorded as cod length increased. In NW Cape Breton, 3 groups of snow crabs were found in cod stomachs: juveniles were most common (ranging from 6 to $44 \mathrm{~mm}$ CW in cod 33 to $82 \mathrm{~cm}$ in length), a second group consisted of larger hard-shelled ovigerous females (49 to $70 \mathrm{~mm} \mathrm{CW}$ in cod 67 to $106 \mathrm{~cm}$ ) and a third group of mainly large soft-shelled (recently moulted) adult males (77 to $107 \mathrm{~mm} \mathrm{CW}$ in cod 49 to $66 \mathrm{~cm}$ ) (Robichaud et al. 1991). In the GSL most of the ingested snow crabs ranged from 5 to $30 \mathrm{~mm}$ CW. Hard-shelled crab larger than $\sim 60$ to $70 \mathrm{~mm}$ CW may not be vulnerable to predation by Atlantic cod in the GSL (Waiwood \& Elner 1982, Robichaud et al. 1991, Chabot et al. 2008). These larger hard-shelled crabs are probably not taken because they aggressively confront and may fend off even large cod (Chabot et al. 2008).

\section{Trends}

In all areas, snow crab abundance and CPUE varied markedly, but generally increased after cod stocks declined. These changes occurred throughout the 1990s at varying times in different regions (Fig. 1). The increase of snow crab abundance in the 1990s occurred both at the warmer (FC) and the colder (NNL) limits of its range, suggesting the increase was not a simple effect of temperature. Temperature varied interannually in all regions (Fig. 1), and a sustained and gradual cooling of waters in ENL, SGSL and NNL leading up to the 1990s was apparent. Atlantic cod biomass recently increased in the warmer regions of the FC and GOM.
Fishery-independent abundance estimates for snow crabs were available in all regions, with the exception of SNL, but were generally of shorter duration (9 to $21 \mathrm{yr}$ ) than fishery CPUE series (20 to $31 \mathrm{yr}$ ) (Table 2, Fig. 3). Despite the shortness of the time series, the fishery CPUE and fishery-independent snow crab time series showed similar trends (Fig. 3). The 2 time series were consistently but weakly positively correlated; however, after accounting for autocorrelation, none of the regions were statistically significant (Fig. 3).

\section{Meta-analysis}

The meta-analytic summaries of the correlation of temperature on Atlantic cod and snow crab (Fig. 4) showed that for cod, the effects of temperature appeared weakly positive at most lags and significant at lags of 1 to 7 yr. For snow crabs, the correlation with temperature was negative at most lags and significant at lags of 7 to $10 \mathrm{yr}$ (Fig. 4). This basic pattern was particularly evident in the colder regions (ENL, the GSL, and the eastern Scotian Shelf [ESS]), and less so in warmer regions (GOM and FC). Both species had significant correlations with temperature at Year 7 in the meta-analytic summary.

Since Atlantic cod biomass and snow crab abundance respectively correlated with temperature positively and negatively, the potential exists to create spurious negative correlations when correlating time series of both species. Hence, we tested for a relationship between Atlantic cod and snow crab by comparing partial correlations (controlling for temperature at a 7 yr lag), and full correlations among time series of the 2 species (Fig. 5). Controlling for the effect of temperature, our meta-analysis revealed significant negative correlations with cod leading snow crab up to $5 \mathrm{yr}$. The full correlations (not accounting for temperature) were statistically significant at positive lags of 0 to 5 and $8 \mathrm{yr}$, and in both the full and partial correlation analyses the strongest effect was observed at a lag of 2 yr, with cod leading snow crab (Fig. 5). Negative correlations at positive lags of 1 to $3 \mathrm{yr}$ were consistent across all individual regions. There was no clear evidence for a bottom-up effect as positive correlations were not statistically significant.

A sensitivity analysis of data with all regions $>500 \mathrm{~km}$ apart did not alter these conclusions. Additional meta-analyses of separate regional groupings produced results that were remarkably consistent with the full analyses (see the supplement at www.intres.com/articles/suppl/m429p169_suppl.pdf). Significant negative correlations remained at the shorter time lags (cod leading snow crab) and were consistent when the GOM and FC (fishery-independent indices) were 


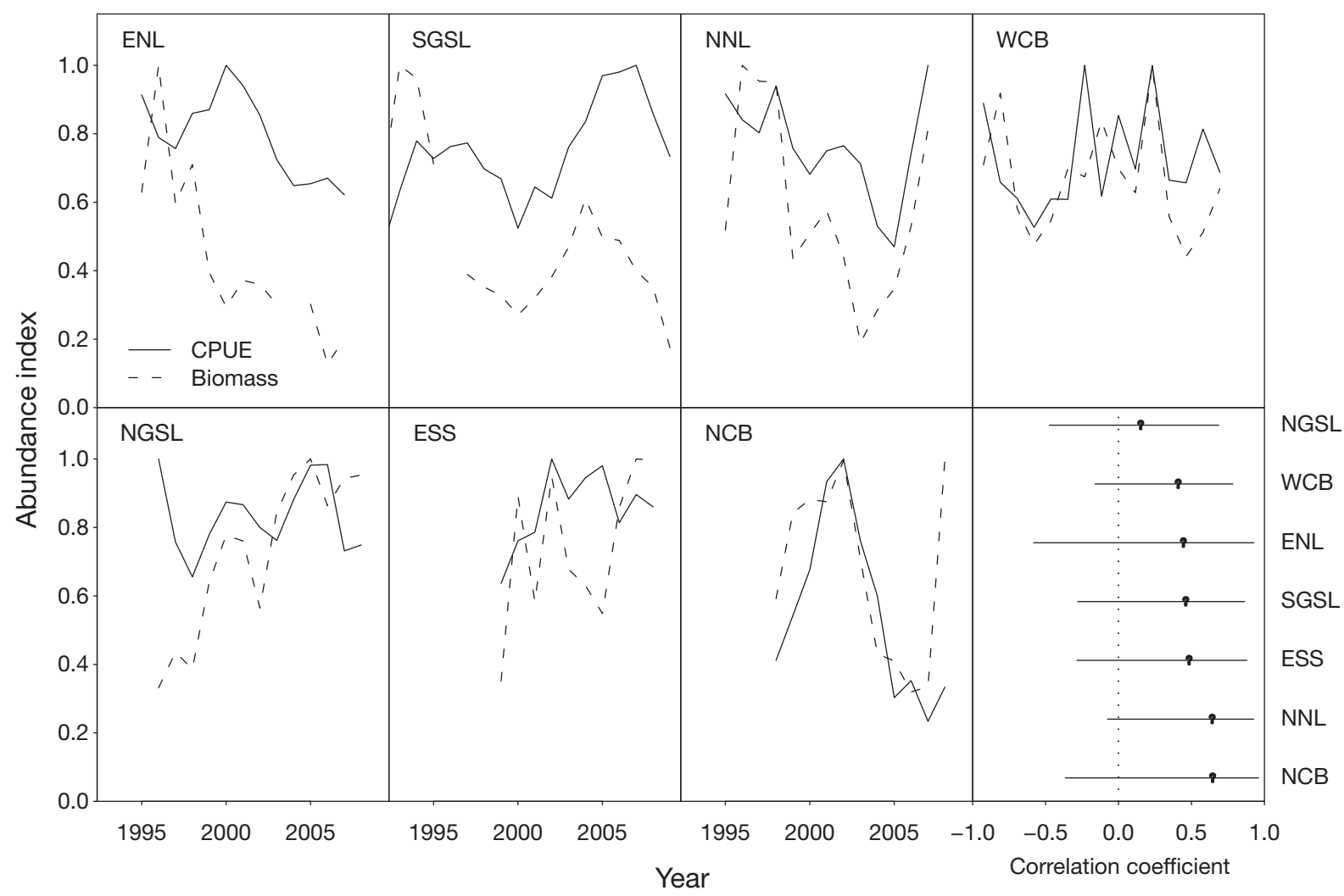

Fig. 3. Chionoecetes opilio abundance estimates. We compared fishery-independent abundance indices (dashed lines) and snow crab fishery CPUE data ( $\mathrm{kg}$ trap haul ${ }^{-1}$, solid lines). Data are scaled relative to the time series maximum. Ranges and units of the fishery-independent biomass indices vary by region: northern Newfoundland (NNL) and eastern Newfoundland (ENL), 1995 to 2006, fishable biomass of mature hard-shelled legal sized males ( $t$ ); southern Gulf of St. Lawrence (SGSL), 1988 to 2009, biomass of post-fishery legal sized males (t); western Cape Breton (WCB), 1993 to 2009, biomass of postfishery legal sized males (t); northern Gulf of St. Lawrence (NGSL), 1996 to 2008, CPUE of postfishery legal sized crabs (kg trap haul ${ }^{-1}$ ); eastern Scotian Shelf (ESS), 1999 to 2008, fishable biomass (t); and northern Cape Breton (NCB), 1998 to 2008, fishable biomass (t). The correlation coefficients of log-transformed fishery CPUE and fishery-independent snow crab indices for each region are displayed in the lower right panel along with $95 \%$ CIs (horizontal bars) corrected for temporal autocorrelation

either included or excluded. One difference concerned the meta-analyses of temperature with cod. When NNL and ENL were the only regions retained in the analyses (Fig. S2 in the supplement), the significantly positive correlations between cod and temperature occurred at longer time lags (10 and $11 \mathrm{yr})$. Similarly, when NNL, ENL and SGSL were the only regions retained (Fig. S3), cod and temperature were significantly positive at lags of 8 to $12 \mathrm{yr}$. These results may be attributed to cod maturing later in Newfoundland than in the rest of Atlantic Canada (ICES 2005).

\section{DISCUSSION}

We tested 3 hypotheses examining the variation in snow crab abundance in the NW Atlantic Ocean. We presented evidence that snow crab is influenced by both ocean temperature and Atlantic cod predation. Increases in crab abundance and CPUE were seen after the collapse of cod stocks. The meta-analyses suggested opposite effects of temperature on cod and snow crab, but still revealed significant negative correlations between cod and crab after accounting for the effect of temperature on each species. There was no clear evidence of a bottom-up effect of snow crab on Atlantic cod. These results suggest that both species interactions and environmental forcing play a role in regulating snow crab abundance in the NW Atlantic Ocean.

The strength of the meta-analytic correlation coefficients at different lags suggests that the effect of climate and predation on snow crab varies with life stage. Snow crab abundance was significantly negatively correlated with temperature between lags of 7 and $10 \mathrm{yr}$, with the strongest correlation at a lag of $8 \mathrm{yr}$ (Fig. 4). This approximates the time of recruitment to the fishery and may indicate that temperature plays a strong role in the early juvenile stages, i.e. the first 3 to $4 \mathrm{yr}$ postsettlement. All life stages of snow crab are 


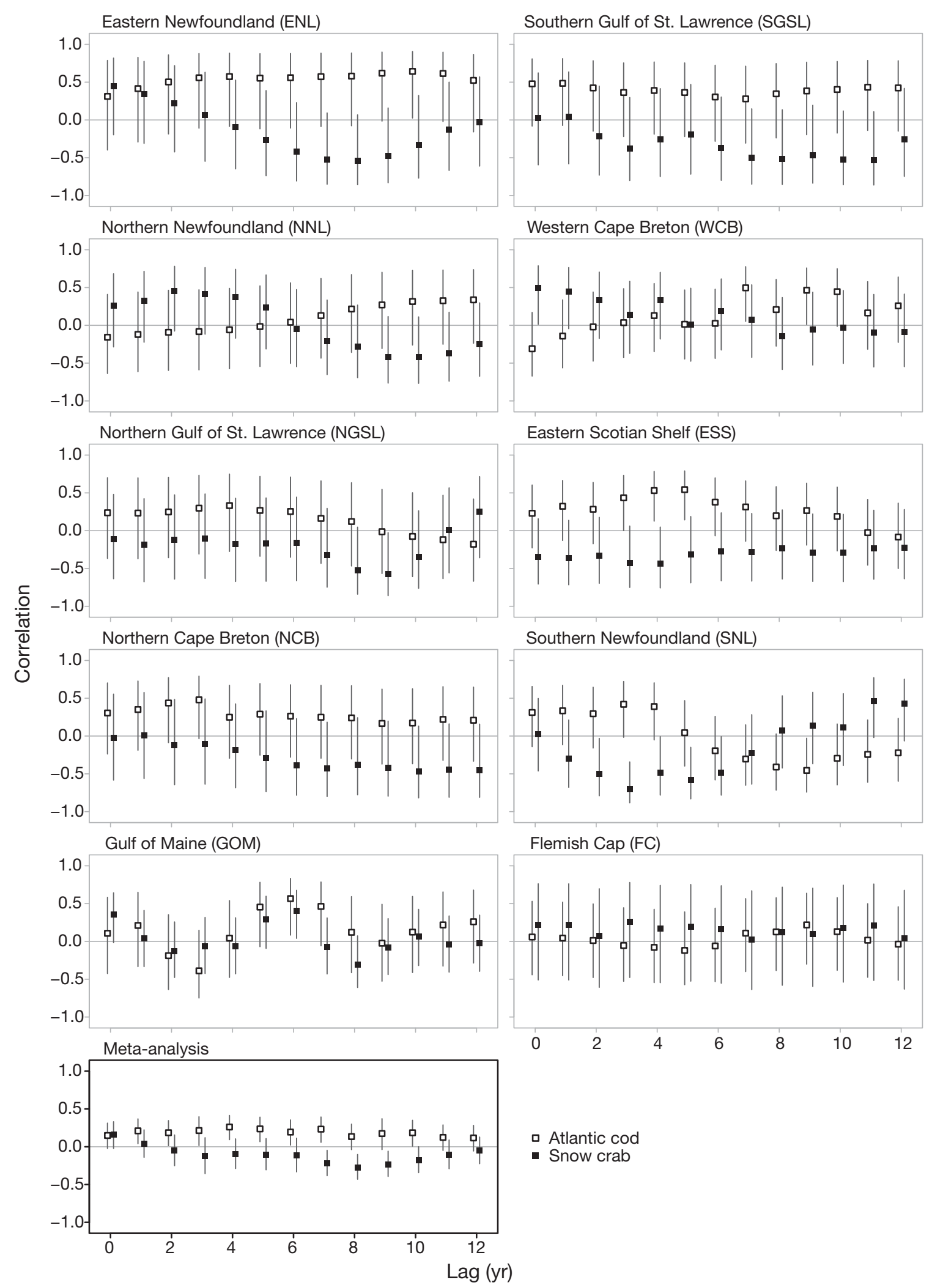

Fig. 4. Gadus morhua and Chionoecetes opilio. Temperature analysis. Shown are the correlation coefficients at various lags between time series of temperature and Atlantic cod (), and temperature and snow crab (घ). Vertical bars illustrate $95 \%$ CIs corrected for autocorrelation. Study regions are arranged from the coldest (eastern Newfoundland) to the warmest (Flemish Cap) median water temperatures. Meta-analysis results are presented in the lower left panel. We explored lags up to $12 \mathrm{yr}$, which reflects the maximum time it takes for snow crab to recruit into the fishery 


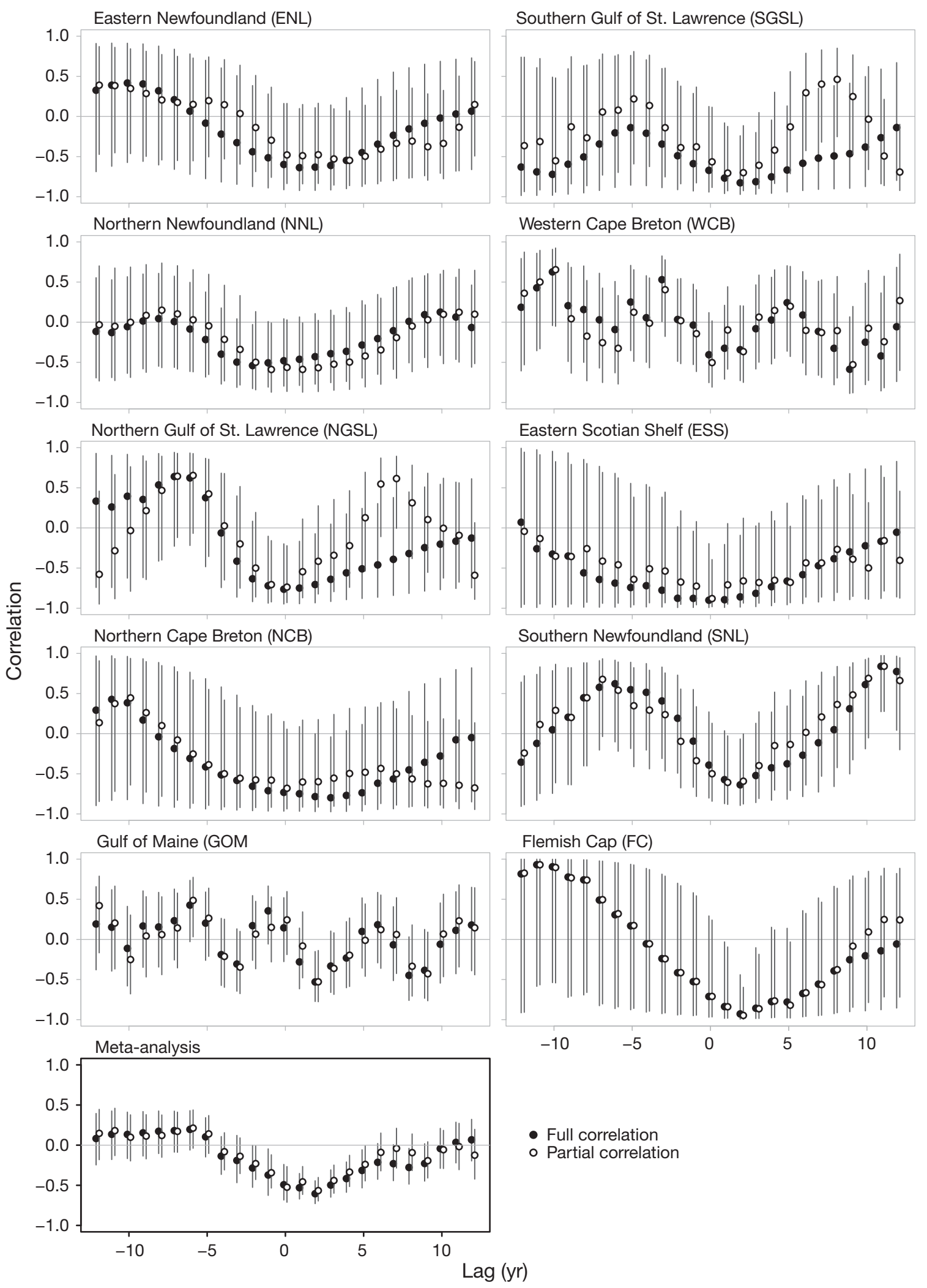

Fig. 5. Gadus morhua and Chionoecetes opilio. Analysis of Atlantic cod-crab interactions. Shown are the full (•) and partial (0) correlation coefficients of snow crab biomass indices with lagged cod biomass indices, along with $95 \%$ CIs (vertical bars) corrected for autocorrelation. Study regions are arranged from the coldest (eastern Newfoundland) to the warmest water temperatures (Flemish Cap). Meta-analysis results are presented in the lower left panel. The partial correlations have been corrected for the effects of temperature at a 7 yr lag 
sensitive to temperature fluctuations (Foyle et al. 1989, Taylor et al. 1993, Conan et al. 1996); however, early juveniles may be the most affected owing to their narrow range of preferred temperatures (Dionne et al. 2003). Cod abundance was positively correlated with temperature at lags of 1 to $7 \mathrm{yr}$, which is consistent with research demonstrating adverse effects of cold temperature on cod growth and condition (e.g. Purchase \& Brown 2001, Dutil \& Brander 2003).

In contrast, top-down forces appeared to have their greatest effect on older juveniles and subadult snow crab. Negative correlations at long time lags (i.e. $>6$ yr, Chabot et al. 2008) would have been expected based on the diet data (Table 1); however, the negative relationship between Atlantic cod and snow crab abundance was strongest at relatively short lags, between 0 and 5 yr, with cod leading snow crab (Fig. 5). According to Sainte-Marie et al. (1995), and assuming that the crab were taken by the fishery in their year of moult, those represented at these short time lags ( 0 to $5 \mathrm{yr}$ ) would be juvenile and subadult crab from $\sim 29 \mathrm{~mm}$ (Instar VII, $3.3 \mathrm{yr}$ of age at moult) to $\sim 97 \mathrm{~mm} \mathrm{CW} \mathrm{(Instar}$ XII, 8.7 yr of age at moult and recruited to the fishery). Commercial catches (i.e. fishery CPUE) and surveys also include males belonging to Instars XIII and XIV; 0 to 5 yr earlier they would have been recently moulted crab of $\sim 38$ to 115 or $\sim 51$ to $136 \mathrm{~mm} \mathrm{CW}$, respectively (Sainte-Marie et al. 1995). While the negative correlations at relatively short time lags are not consistent with what is presently known of Atlantic cod predation on snow crab, we noted that most of these values fell within the range of the larger snow crab recorded in diet studies (Table 1), with the exception of the largest (115 and $136 \mathrm{~mm} \mathrm{CW).} \mathrm{Our} \mathrm{results} \mathrm{were} \mathrm{robust} \mathrm{across}$ alternative combinations of areas (see supplement); however, it is likely that larger crabs (i.e. $>65$ to $70 \mathrm{~mm}$ CW, Table 1) would have to be ingested in postmoult condition (i.e. soft-shelled), as larger hard-shelled crabs are not present in diet studies.

The regions selected for this study all show spatial and temporal overlap between snow crab and Atlantic cod stocks (Table 1); however, predation effects might not play out across their range owing to, for example, seasonal migration of cod (e.g. the GSL, Chabot et al. 2008 and references therein), but may be concentrated on smaller spatial and temporal scales (Link \& Garrison 2002). For example, off Labrador (both inshore and offshore) a dietary shift along the coast was observed in Atlantic cod from fish in the south (e.g. capelin Mallotus villosus) to crustaceans in the north (e.g. snow crab). This spatial diet shift was attributed to the distribution of their prey species (Lee \& Khan 2000). Similar variation may occur over time, for example, if predation occurs on larger, defenseless crab during moulting (Robichaud et al. 1991, Chabot et al. 2008).
In the GSL, large snow crab moult in high-density aggregations during early spring, February to April in the SGSL (Hébert et al. 2002) and March to June in the NGSL (Sainte-Marie \& Hazel 1992, Lovrich et al. 1995), in shallow water $(<35$ m, Sainte-Marie \& Hazel 1992, Sainte-Marie 1993, Lovrich et al. 1995), possibly to avoid predation (Lovrich et al. 1995, Comeau et al. 1998, Chabot et al. 2008). Atlantic cod typically begin to migrate back into the SGSL by mid-April (ICES 2005) and into the NGSL in April and May for spawning, and then disperse along the coast (DFO 2010b). Chabot et al. (2008) examined additional SGSL cod stomachs for the presence of soft-shelled crab. They discovered a low incidence $(0.9 \%)$ of large soft-shelled snow crab ( $\geq 79 \mathrm{~mm} \mathrm{CW}$ ) in larger cod from the eastern SGSL, in the same locations as in Robichaud et al. (1991) (Table 1). All age classes of cod return to the eastern portion of the SGSL during the spring (by midMay) (Hanson 1996), increasing the overlap between cod and soft-shell male snow crabs (Chabot et al. 2008). Large male snow crabs recover from postmoult (soft-shelled) condition to a hard carapace in 2 to 3 mo (Watson 1971, O'Halloran \& O'Dor 1988, Taylor et al. 1989, Hébert et al. 2002), sometimes longer (Godbout et al. 2002). This would indicate that soft-shelled crabs, especially late-moulting individuals, could be available to Atlantic cod for part of their spring/summer migration. Further research on this issue should focus on the extent of temporal and spatial overlap between Atlantic cod and moulting snow crab as well as cod predation on sublegal and legal sized crabs in softshell condition. This may occur, for example, in poorly assessed coastal areas where moulting snow crabs tend to aggregate (Sainte-Marie \& Hazel 1992, Lovrich et al. 1995). It is presently unclear how strong a role predation may play in regulating snow crab abundance during this vulnerable life stage.

Other studies provide some evidence that Atlantic cod could influence abundance of snow crab. In the SGSL, Bailey (1982) found a negative correlation between commercial-sized snow crab (landings) and the biomass of Atlantic cod at a 3 to 6 yr lag. Bailey (1982) suggested that snow crabs were vulnerable to predation during their first 3 yr postsettlement, although this result was based on short time series. A later study in the same region found a significant negative correlation $(\mathrm{r}=-0.66)$ between snow crab landings and Atlantic cod abundance at a lag of $10 \mathrm{yr}$, yet concluded that density-dependent mechanisms were more likely responsible for the variation in snow crab abundance (Caddy et al. 2005). A third study reported that snow crab is vulnerable to predation by Atlantic cod for the first $\sim 5$ yr postsettlement in the GSL, which could be detected in the snow crab fishery 6 to 11 yr later (Chabot et al. 2008). On the ESS, Frank et al. (2005) 
found a strong negative correlation $(\mathrm{r}=-0.70)$ between benthic fish biomass and snow crab abundance, without assuming a time lag. Further, Shackell et al. (2009) presented evidence that the declining individual size of predators on the Scotian Shelf could have top-down effects that are independent of changes in total biomass. That study noted that according to trawl surveys, the aggregated biomass of 'large-bodied' predatory fish had been stable for 4 decades while the biomass of their prey species had doubled in 11 yr. Declines in predator body size largely accounted for the increase in aggregate prey biomass, suggesting a potential reduction in predator energy requirements and their maximum potential size of prey. A pattern of decline in average Atlantic cod length is not unique to the Scotian Shelf and has been recorded in much of the NW Atlantic Ocean (Worcester et al. 2009). These results from individual ecosystems could be further tested by the meta-analytic approach presented here.

Our results have focused on Atlantic cod, which in many areas of the NW Atlantic was probably an important predator of snow crab (Table 1); however, the decline of cod coincided with declines of other large groundfishes (Casey 2000, Frank et al. 2005). For example, total groundfish biomass in Newfoundland decreased by nearly an order of magnitude between 1950 and 1995 (Myers \& Worm 2003). Some of these other species may have been important predators of crab. For example, some skates may consume more snow crab than do Atlantic cod (Robichaud et al. 1991). Atlantic cod are described as opportunistic generalists, and while they exhibit preferences throughout their ontogeny, it is unlikely that they control the abundance of all potential prey species (e.g. Link \& Garrison 2002). Atlantic cod may be opportunistically preying on snow crab in years when juveniles are abundant (Waiwood \& Elner 1982, Chabot et al. 2008), and therefore the strength of predator top-down control may vary across time and regions.

We interpret our results as evidence of temperature control on early juvenile snow crab and top-down control on older juvenile and subadult stages. The alternative hypothesis of bottom-up control was not supported by our analysis. Under this scenario, if both populations were primarily influenced by resource availability, we would expect positive correlations across a range of lags. Additionally, we encountered negative meta-analytic correlations at negative lags, which could imply top-down control of snow crab on Atlantic cod. Such a scenario could be plausible because fish are present in the diet of larger snow crab (Wieczorek \& Hooper 1995, Lovrich \& Sainte-Marie 1997, Squires \& Dawe 2003); however, these correlations attenuated quickly towards zero and were marginally significant. It is possible that these correlations are not biologically meaningful, given that some degree of serial autocorrelation is expected in the cross-correlation between 2 nonrandom time series at successive lags.

Other variables, such as wind-driven upwellings, sea ice coverage (e.g. Conan et al. 1996, Dawe et al. 2008) or density dependence (e.g. cannibalism, Lovrich \& Sainte-Marie 1997) could be influencing snow crab populations in ways not accounted for by our analysis. Another possibility could be direct competition between the 2 species, as they both prey on benthic invertebrates such as small crustaceans (i.e. shrimp, crab) and molluscs (Waiwood \& Majkowski 1984, Wieczorek \& Hooper 1995, Casas \& Paz 1996, Lovrich \& Sainte-Marie 1997, Hanson \& Chouinard 2002, Squires \& Dawe 2003). The importance of top-down and bottom-up forces may vary between areas (Figs. 4 \& 5), although some mechanistic generalities have emerged from the present analysis.

One important limitation of our study is that much of the inference is based on snow crab fishery CPUE data. Fishery CPUE can underestimate (hyperdepletion) or overestimate (hyperstability) abundance depending on the behaviour and distribution of both fishers and their target species (Harley et al. 2001). In the present study, there are inherent differences in how the abundance indices (i.e. fishery dependent and fishery independent) were collected. Snow crab fishery CPUE (kg trap haul $^{-1}$ ) was weakly and not significantly positively correlated with abundance indices in all regions, yet showed trends similar to the fishery-independent survey data (research trawl surveys; $\mathrm{t}$ or $\mathrm{kg} \mathrm{tow}^{-1}$ ) (Fig. 1), which supports the use of CPUE in the analysis.

Snow crab is also found in the north Pacific Ocean where researchers examined various hypotheses, including the top-down and bottom-up (climate control) mechanisms explored in the present study, to explain abundance trends for snow crab populations in Alaska. Commercial snow crab stocks showed highly variable recruitment in Alaska, which is reflected in their population abundance (Zheng \& Kruse 2006). In the eastern Bering Sea (EBS), snow crab recruitment has been weakly negatively correlated with sea surface temperature (Zheng \& Kruse 2000). There is also evidence that the range of snow crab in the EBS has contracted to the north owing to large-scale warming in the late 1970s, and although the water has since cooled, their range has not re-expanded south. Orensanz et al. (2004) suggested that currents preventing the advection of larvae to the southern EBS or predation on prerecruits by $\mathrm{Pa}$ cific cod Gadus macrocephalus might be preventing the snow crab's re-expansion. While Pacific cod prey upon snow crab (Livingston 1989), their regulatory role is also debated as Pacific cod did not emerge as a driving factor in explaining EBS snow crab recruitment variability (time lags of 0 to 4 yr) (Zheng \& Kruse 2000, 
2006). There is therefore some evidence that bottom-up (climate forcing) and top-down (groundfish predation) mechanisms jointly control commercial crab recruitment in the EBS (Zheng \& Kruse 2000, 2006, Orensanz et al. 2004). However, these studies were based on single time series analyses, and therefore the metaanalytic approach employed in the present analysis may be a more powerful tool that can be used to evaluate these general hypotheses by addressing the regulation of species abundances across several large marine ecosystems. Any meta-analytic approach represents a trade-off between generality and local detail, as individual regions may vary in their responses and averaged results may be of limited value for predicting local response to changes in the environment.

In conclusion, based on the available evidence from multiple time series, this analysis supports both the climate and top-down hypotheses. We suggest that the observed fluctuations in snow crab abundance are driven partly by temperature and partly by the variation in Atlantic cod abundance. The results suggest that temperature has a stronger influence on snow crab abundance during the first few years postsettlement and its importance may lessen as top-down mechanisms begin to play a larger regulatory role. In the wake of the groundfish collapse of the 1990s, Atlantic Canadian fisheries have become increasingly dependent on invertebrates, and the snow crab fishery is among the 3 most valuable today. The knowledge gained from this analysis would be useful in a management context when possible changes to snow crab stocks are anticipated as water temperature and groundfish abundance change over time. The meta-analytic approach is a useful tool for detecting general trends from relatively short time series and providing insight into regulating forces across regions. Meta-analysis of partial correlation coefficients may be used more generally to detect the relative effects of a changing climate, as well as the ecosystem effects of fishing, on species communities in the North Atlantic Ocean and elsewhere.

Acknowledgements. We gratefully acknowledge the late R. A. Myers for initiating the present study and for his inspiration and guidance. Special thanks to W. Blanchard for helping to develop the methods presented here, statistical support and helpful discussions. We are grateful to J. Brattey, R. W. Brown, J. S. Choi, E. G. Dawe, M. Fowler, H. K. Lotze, M. Moriyasu, C. Muir, B. Sainte-Marie, A. Seaver, D. P. Swain, J. Tremblay and A. Vázquez for providing data, helpful comments and insights, and to R. Miller for recovering historical Newfoundland snow crab CPUE data. We thank 2 anonymous reviewers for their thorough reviews, which have significantly improved the manuscript. Financial support is acknowledged from the Natural Sciences and Engineering Research Council of Canada and the Sloan Foundation (Census of Marine Life Program, Future of Marine Animal Populations Project).

\section{LITERATURE CITED}

Anderson SC, Lotze HK, Shackell NL (2008) Evaluating the knowledge base for expanding low-trophic level fisheries in Atlantic Canada. Can J Fish Aquat Sci 65:2553-2571

Bailey RF (1982) Relationship between catches of snow crab, C. opilio (O. Fabricus) and abundance of cod (Gadus morhua L.) in the southwestern Gulf of St. Lawrence. In: Proceedings of the International Symposium on the Genus Chionoecetes, May 3-6, 1982. University of Alaska Sea Grant, Anchorage, AK, p 483-498

Bailey RJF, Elner RW (1989) Northwest Atlantic snow crab fisheries: lessons in research and management. In: Caddy JF (ed) Marine invertebrate fisheries: their assessment and management. John Wiley and Sons, New York, NY, p 261-280

Biron M, Savoie L, Campbell R, Wade E, Moriyasu M, DeGrâce P, Gautreau R (2001) Assessment of the 2000 snow crab (Chionoecetes opilio) fishery off eastern Nova Scotia (Areas 20-24). DFO Can Sci Advis Secretariat Res Doc 2001/017

Bishop CA, Anderson J, Dalley E, Davis MB, Murphy EF, Rose GA, Stansbury DE, Taggart C, Winters G (1994) An assessment of the cod stock in NAFO divisions $2 \mathrm{~J}+3 \mathrm{KL}$. Northwest Atl Fish Org Sci Counc Res Doc 94/40, Ser No 2410

Brattey J, Cadigan NG, Dwyer K, Healey BP, Morgan MJ, Murphy EF, Maddock Parsons D, Power D (2009) Assessment of the cod (Gadus morhua) stock in NAFO divisions $2 \mathrm{~J}+3 \mathrm{KL}$ in 2009. DFO Can Sci Advis Secretariat Res Doc 2009/061

Caddy JF, Wade E, Surette T, Hebert M, Moriyasu M (2005) Using an empirical traffic light procedure for monitoring and forecasting in the Gulf of St. Lawrence fishery for the snow crab, Chionoecetes opilio. Fish Res 76:123-145

Casas JM, Paz J (1996) Recent changes in the feeding of cod (Gadus morhua) off the Flemish Cap, Newfoundland 1989-1993. ICES J Mar Sci 53:750-756

Casey JM (2000) Fish community changes in an exploited marine ecosystem: Newfoundland southern Grand Bank and St. Pierre Bank 1951-1995. MSc thesis, Memorial University of Newfoundland, St. John's

Chabot D, Sainte-Marie B, Briand K, Hanson JM (2008) Atlantic cod and snow crab predator-prey size relationship in the Gulf of St. Lawrence, Canada. Mar Ecol Prog Ser 363:227-240

Choi JS, Zisserson BM (2008) An assessment of the snow crab resident on the Scotian Shelf in 2006, focusing upon CFA 4X. DFO Can Sci Advis Secretariat Res Doc 2008/003

Chouinard GA, Currie L, Poirier G (2001) Assessment of cod in the southern Gulf of St. Lawrence, February 2001. DFO Can Sci Advis Secretariat Res Doc 2001/020

Comeau M, Conan GY, Maynou F, Robichaud G, Therriault JC, Starr M (1998) Growth, spatial distribution, and abundance of benthic stages of the snow crab (Chionoecetes opilio) in Bonne Bay, Newfoundland, Canada. Can J Fish Aquat Sci 55:262-279

> Comeau M, Starr M, Conan GY, Robichaud G, Therriault JC (1999) Fecundity and duration of egg incubation for multiparous female snow crab (Chionoecetes opilio) in the fjord of Bonne Bay, Newfoundland. Can J Fish Aquat Sci 56: 1088-1095

> Conan GY, Comeau M (1986) Functional maturity and terminal molt of male snow crab, Chionoecetes opilio. Can J Fish Aquat Sci 43:1710-1719

Conan GY, Starr M, Comeau M, Therriault JC, Hernàndez FXM, Robichaud G (1996) Life history strategies, recruitment fluctuations, and management of the Bonne Bay 
Fjord Atlantic snow crab (Chionoecetes opilio). In: High latitude crabs: biology, management, and economics. Prog Rep 96-02, Alaska Sea Grant College, Anchorage AK, p 59-97

Dawe EG, Parsons DG, Colbourne EB (2008) Relationships of sea ice extent and bottom water temperature with abundance of snow crab (Chionoectes opilio) on the Newfoundland-Labrador Shelf. ICES CM 2008/B:02, Copenhagen

DFO (Department of Fisheries and Oceans Canada) (2007) Assessment of Newfoundland and Labrador snow crab. DFO Can Sci Advis Secretariat Sci Advis Rep 2007/008

DFO (Department of Fisheries and Oceans Canada) (2009a) 2008 Value of Atlantic coast commercial landings, by region. www.dfo-mpo.gc.ca/stats/commercial/landdebarq/sea-maritimes/s2008av-eng.htm (modified 10 Oct 2009, accessed 14 Dec 2009)

DFO (Department of Fisheries and Oceans Canada) (2009b) Assessment of Nova Scotia (4VWX) snow crab. DFO Can Sci Advis Secretariat Sci Advis Rep 2009/053

DFO (Department of Fisheries and Oceans Canada) (2009c) Assessment of Newfoundland and Labrador snow crab. DFO Can Sci Advis Secretariat Sci Advis Rep 2009/045

DFO (Department of Fisheries and Oceans Canada) (2009d) Assessment of snow crab in the southern Gulf of St. Lawrence (Areas 12, 19, E and F). DFO Can Sci Advis Secretariat Sci Advis Rep 2009/006

DFO (Department of Fisheries and Oceans Canada) (2009e) Assessment of the Estuary and northern Gulf of St. Lawrence (Areas 13 to $17,12 \mathrm{~A}, 12 \mathrm{~B}, 12 \mathrm{C}$ and 16A) snow crab stocks in 2008. DFO Can Sci Advis Secretariat Sci Advis Rep 2009/027

DFO (Department of Fisheries and Oceans Canada) (2009f) Assessment of cod stock in the northern Gulf of St. Lawrence (3Pn, 4RS) in 2008. DFO Can Sci Advis Secretariat Sci Advis Rep 2009/010

DFO (Department of Fisheries and Oceans Canada) (2009g) Stock assessment of subdivision 3Ps cod. DFO Can Sci Advis Secretariat Sci Advis Rep 2009/008

DFO (Department of Fisheries and Oceans Canada) (2010a) Assessment of snow crab in the southern Gulf of St. Lawrence (Areas 12, 19, 12E and 12F). DFO Can Sci Advis Secretariat Sci Advis Rep 2010/015

DFO (Department of Fisheries and Oceans Canada) (2010b) Assessment of cod stock in the northern Gulf of St. Lawrence (3Pn, 4RS) in 2009. DFO Can Sci Advis Secretariat Sci Advis Rep 2010/011

Dionne M, Sainte-Marie B, Bourget E, Gilbert D (2003) Distribution and habitat selection of early benthic stages of snow crab Chionoecetes opilio. Mar Ecol Prog Ser 259: $117-128$

Dutil JD, Brander K (2003) Comparing productivity of North Atlantic cod (Gadus morhua) stocks and limits to growth production. Fish Oceanogr 12:502-512

Elner RW (1982) Overview of snow crab Chionoecetes opilio fishery in Atlantic Canada. In: Proceedings of the International Symposium on the Genus Chionoecetes. Lowell Wakefield Fish Symp Ser, University of Alaska, Alaska Sea Grant Rep 82-10, p 3-19

Fanning LP, Mohn RK, MacEachern WJ (2003) Assessment of $4 \mathrm{VsW}$ cod to 2002. DFO Can Sci Advis Secretariat Res Doc 2003/027

Fonseca DB, Sainte-Marie B, Hazel F (2008) Longevity and change in shell condition of adult male snow crab Chionoecetes opilio inferred from dactyl wear and mark-recapture data. Trans Am Fish Soc 137:1029-1043

Foyle TP, O'Dor RK, Elner RW (1989) Energetically defining the thermal limits of the snow crab. J Exp Biol 145: 371-393
Frank KT, Petrie B, Choi JS, Leggett WC (2005) Trophic cascades in a formerly cod-dominated ecosystem. Science 308:1621-1623

> Frank KT, Petrie B, Shackell NL (2007) The ups and downs of trophic control in continental shelf ecosystems. Trends Ecol Evol 22:236-242

> Godbout G, Dutil JD, Hardy D, Munro J (2002) Growth and condition of post-moult male snow crab (Chionoecetes opilio) in the laboratory. Aquaculture 206:323-340

Gonzalez-Troncoso D, Fernandez C (2009) Assessment of the cod stock in NAFO Division 3M. Northwest Atl Fish Org Sci Counc Res Doc 09/034

Gregory DN (2004) Climate: a database of temperature and salinity observations for the Northwest Atlantic. DFO Can Sci Advis Secretariat Res Doc 2004/075

Hanson JM (1996) Seasonal distribution of juvenile Atlantic cod in the southern Gulf of St. Lawrence. J Fish Biol 49: 1138-1152

Hanson JM, Chouinard GA (2002) Diet of Atlantic cod in the southern Gulf of St. Lawrence as an index of ecosystem change, 1959-2000. J Fish Biol 60:902-922

> Harley SJ, Myers RA, Dunn A (2001) Is catch-per-unit-effort proportional to abundance? Can J Fish Aquat Sci 58: 1760-1772

Hébert M, Wade E, DeGrâce P, Bélanger P, Moriyasu M (2008) The 2007 assessment of snow crab, Chionoecetes opilio, stocks in the southern Gulf of St. Lawrence (Areas 12, 19, E and F). DFO Can Sci Advis Secretariat Res Doc $2008 / 040$

Hébert M, Wade E, Surette T, Moriyasu M (2001) The 2000 assessment of snow crab (Chionoecetes opilio) in the southern Gulf of St. Lawrence (Areas 12-25/26, E and F). DFO Can Sci Advis Secretariat Res Doc 2001/15

> Hébert M, Benhalima K, Miron G, Moriyasu M (2002) Moulting and growth of male snow crab, Chionoecetes opilio (O. Fabricius, 1788) (Decapoda, Majidae), in the southern Gulf of St. Lawrence. Crustaceana 75:671-702

Hedges LV (1994) Fixed effects models. In: Cooper H, Hedges LV (eds) The handbook of research synthesis. Russell Sage Foundation, New York, NY, p 285-299

> Hutchings JA (1996) Spatial and temporal variation in the density of northern cod and a review of hypotheses for the stock's collapse. Can J Fish Aquat Sci 53:943-962

ICES (International Council for the Exploration of the Sea) (2005) Spawning and life history information for North Atlantic cod stocks. ICES Coop Res Rep No. 274, Copenhagen

> Lee EM, Khan RA (2000) Length-weight-age relationships, food, and parasites of Atlantic cod (Gadus morhua) off coastal Labrador within NAFO Divisions $2 \mathrm{H}$ and $2 \mathrm{~J}-3 \mathrm{~K}$. Fish Res 45:65-72

Lilly GR (1984) Predation by Atlantic cod on shrimp and crabs off northeastern Newfoundland in autumn of 1977-82. ICES CM 1984/G 53:1-25, Copenhagen

Lilly G, Murphy E, Healey B, Brattey J (2006) An assessment of the cod (Gadus morhua) stock in NAFO Divisions 2J3KL in April 2006. DFO Can Sci Advis Secretariat Res Doc 2006/043

> Link JS, Garrison LP (2002) Trophic ecology of Atlantic cod Gadus morhua on the northeast US continental shelf. Mar Ecol Prog Ser 227:109-123

Livingston P (1989) Interannual trends in Pacific cod, Gadus macrocephalus, predation on three commercially important crab species in the Eastern Bering Sea. Fish Bull 87: 807-827

Lovrich GA, Sainte-Marie B (1997) Cannibalism in the snow crab, Chionoecetes opilio (Brachyura: Majidae), and its potential importance to recruitment. J Exp Mar Biol Ecol 211:225-245 
Lovrich GA, Sainte-Marie B, Smith BD (1995) Depth distribution and seasonal movements of Chionoectes opilio (Brachyura: Majidae) in Baie Sainte-Marguerite, Gulf of Saint Lawrence. Can J Zool 73:1712-1726

Miller RJ (1976) North American crab fisheries: regulations and their rationales. Fish Bull 74:623-633

> Murray LG, Seed R (2010) Determining whether catch per unit effort is a suitable proxy for relative crab abundance. Mar Ecol Prog Ser 401:173-182

Myers RA, Cadigan NG (1995) Was an increase in natural mortality responsible for the collapse of northern cod? Can J Fish Aquat Sci 52:1274-1285

> Myers RA, Worm B (2003) Rapid worldwide depletion of predatory fish communities. Nature 423:280-283

Myers RA, Hutchings JA, Barrowman NJ (1996) Hypotheses for the decline of cod in the North Atlantic. Mar Ecol Prog Ser 138:293-308

Myers RA, Hutchings JA, Barrowman NJ (1997a) Why do fish stocks collapse? The example of cod in Atlantic Canada. Ecol Appl 7:91-106

Myers RA, Mertz G, Bridson JM (1997b) Spatial scales of interannual recruitment variations of marine, anadromous, and freshwater fish. Can J Fish Aquat Sci 54: 1400-1407

NEFSC (Northeast Fisheries Science Center) (2008) Assessment of 19 northeast groundfish stocks through 2007: report of the 3rd Groundfish Assessment Review Meeting (GARM III). NOAA NEFSC Res Doc 08/15, Woods Hole, MA

O'Halloran M, O'Dor R (1988) Molt cycle of male snow crabs, Chionoecetes opilio, from observations of external features, setal changes, and feeding behavior. J Crustac Biol 8:164-176

Orensanz JL, Ernst B, Armstrong DA, Stabeno P, Livingston P (2004) Contraction of the geographic range of distribution of snow crab (Chionoecetes opilio) in the eastern Bering Sea: an environmental ratchet? Calif Coop Oceanic Fish Invest Rep 45:67-79

Pálsson ÓK (1994) A review of the trophic interactions of cod stocks in the north Atlantic. ICES Mar Sci Symp 198: 553-575

> Purchase CF, Brown JA (2001) Stock-specific changes in growth rates, food conversion efficiencies, and energy allocation in response to temperature change in juvenile Atlantic cod. J Fish Biol 58:36-52

Pyper BJ, Peterman RM (1998) Comparison of methods to account for autocorrelation in correlation analysis of fish data. Can J Fish Aquat Sci 55:2127-2140

Robichaud DA, Elner R, Bailey R (1991) Differential selection of crab Chionoecetes opilio and Hyas spp. as prey by sympatric cod Gadus morhua and thorny skate Raja radia. Fish Bull 89:669-680

Sainte-Marie B (1993) Reproductive cycle and fecundity of primiparous and multiparous female snow crab, Chionoecetes opilio, in the northwest Gulf of Saint Lawrence. Can J Fish Aquat Sci 50:2147-2156

Sainte-Marie B, Hazel F (1992) Moulting and mating of snow crabs, Chionoecetes opilio (O. Fabricius), in shallow waters of the northwestern Gulf of Saint Lawrence. Can J Fish Aquat Sci 49:1282-1293

Sainte-Marie B, Lafrance M (2002) Growth and survival of recently settled snow crab Chionoecetes opilio in relation to intra- and intercohort competition and cannibalism: a laboratory study. Mar Ecol Prog Ser 244:191-203

Sainte-Marie B, Raymond S, Brêthes JC (1995) Growth and maturation of benthic stages of male snow crab, Chionoecetes opilio (Brachyura: Majidae). Can J Fish Aquat Sci 52:903-924

Editorial responsibility: Hans Heinrich Janssen, Oldendorf/Luhe, Germany
Sainte-Marie B, Sevigny J, Smith BD, Lovrich GA (1996) Recruitment variability in snow crab (Chionoecetes opilio): pattern, possible causes, and implications for fishery management. In: High latitude crabs: biology, management, and economics. Alaska Sea Grant College Program, AKSG-96-02, Fairbanks, AK, p 451-477

Shackell NL, Frank KT, Fisher JAD, Petrie B, Leggett WC (2009) Decline in top predator body size and changing climate alter trophic structure in an oceanic ecosystem. Proc R Soc B 277:1353-1360

Squires HJ, Dawe EG (2003) Stomach contents of snow crab (Chionoecetes opilio, Decapoda, Brachyura) from the Northeast Newfoundland Shelf. J Northwest Atl Fish Sci $32: 27-38$

Stuart A, Ord JK (1987) Kendall's advanced theory of statistics, Vol 1. Distribution theory. Oxford University Press, New York, NY

Swain DP, Wade EJ (2003) Spatial distribution of catch and effort in a fishery for snow crab (Chionoecetes opilio): tests of predictions of the ideal free distribution. Can J Fish Aquat Sci 60:897-909

Swain DP, Savoie L, Hurlbut T, Surette T, Daigle D (2009) Assessment of the southern Gulf of St. Lawrence cod stock, February 2009. DFO Can Sci Advis Secretariat Res Doc 2009/037

Taylor DM, Marshall GW, O'Keefe PG (1989) Shell hardening in snow crabs Chionoecetes opilio tagged in soft-shelled condition. N Am J Fish Manag 9:504-508

Taylor DM, O'Keefe P, Fitzpatrick C (1993) A snow crab, Chionoecetes opilio (Decapoda, Majidae), fishery collapse in Newfoundland. Fish Bull 92:412-419

- Tremblay MJ (1997) Snow crab (Chionoecetes opilio) distribution limits and abundance trends on the Scotian Shelf. J Northwest Atl Fish Sci 21:7-21

Vázquez A, Cervino S (2002) Assessment of the cod stock in NAFO Division 3M. Northwest Atl Fish Org Sci Counc Rep Doc 02/58

Waiwood KG, Elner RW (1982) Cod predation of snow crab (Chionoecetes opilio) in the Gulf of St. Lawrence. In: Proceedings of the International Symposium on the Genus Chionoecetes, 3-6 May 1982. University of Alaska Sea Grant, Anchorage, AK, p 499-520

Waiwood K, Majkowski J (1984) Food consumption and diet composition of cod, Gadus morhua, inhabiting the southwestern Gulf of St. Lawrence. Environ Biol Fishes 11: $63-78$

- Watson J (1971) Ecdysis of the snow crab, Chionoecetes opilio. Can J Zool 49:1025-1027

> Wieczorek SK, Hooper RG (1995) Relationship between diet and food availability in the snow crab Chionoecetes opilio (O. Fabricius) in Bonne Bay, Newfoundland. J Crustac Biol 15:236-247

Worcester T, Brattey J, Chouinard GA, Clark D, Clark KJ, Deault J, Fowler M, Fréchet A and others (2009) Status of Atlantic cod (Gadus morhua) in 2008. DFO Can Sci Advis Secretariat Res Doc 2009/027

Worm B, Myers RA (2003) Meta-analysis of cod-shrimp interactions reveals top-down control in oceanic food webs. Ecology 84:162-173

Zheng J, Kruse GH (2000) Recruitment patterns of Alaskan crabs in relation to decadal shifts in climate and physical oceanography. ICES J Mar Sci 57:438-451

Zheng J, Kruse GH (2006) Recruitment variation of eastern Bering Sea crabs: climate-forcing or top-down effects? Prog Oceanogr 68:184-204

Submitted: September 21, 2010; Accepted: February 9, 2011 Proofs received from author(s): May 8, 2011 